\title{
Article \\ Functional Coupling of Slack Channels and P2X3 Receptors Contributes to Neuropathic Pain Processing
}

\author{
Ruirui Lu ${ }^{1, *}$, Katharina Metzner ${ }^{1}$, Fangyuan Zhou ${ }^{1}$, Cathrin Flauaus ${ }^{1}$, Annika Balzulat ${ }^{1}$, Patrick Engel ${ }^{1}$, \\ Jonas Petersen ${ }^{1}$, Rebekka Ehinger ${ }^{2}$, Anne Bausch ${ }^{2}$, Peter Ruth ${ }^{2}$, Robert Lukowski ${ }^{2}$ and Achim Schmidtko ${ }^{1}$ \\ 1 Institut für Pharmakologie und Klinische Pharmazie, Goethe-Universität Frankfurt am Main, \\ 60438 Frankfurt am Main, Hessen, Germany; Metzner@em.uni-frankfurt.de (K.M.); \\ Zhou@stud.uni-frankfurt.de (F.Z.); flauaus@em.uni-frankfurt.de (C.F.); Balzulat@em.uni-frankfurt.de (A.B.); \\ p.engel@em.uni-frankfurt.de (P.E.); J.Petersen@em.uni-frankfurt.de (J.P.); \\ schmidtko@em.uni-frankfurt.de (A.S.) \\ 2 Pharmakologie, Toxikologie und Klinische Pharmazie, Institut für Pharmazie, Universität Tübingen, \\ 72076 Tübingen, Baden-Württemberg, Germany; rebekka.dieter@uni-tuebingen.de (R.E.); \\ anne.bausch@rpt.bwl.de (A.B.); peter.ruth@uni-tuebingen.de (P.R.); robert.lukowski@uni-tuebingen.de (R.L.) \\ * Correspondence: Lu@em.uni-frankfurt.de; Tel.: +49-69-798-29377
}

\section{check for} updates

Citation: Lu, R.; Metzner, K.; Zhou, F.; Flauaus, C.; Balzulat, A.; Engel, P.;

Petersen, J.; Ehinger, R.; Bausch, A.; Ruth, P.; et al. Functional Coupling of Slack Channels and P2X3 Receptors Contributes to Neuropathic Pain Processing. Int. J. Mol. Sci. 2021, 22, 405. https://doi.org/10.3390/ijms 22010405

Received: 23 November 2020 Accepted: 29 December 2020 Published: 2 January 2021

Publisher's Note: MDPI stays neutral with regard to jurisdictional clai$\mathrm{ms}$ in published maps and institutional affiliations.

Copyright: (C) 2021 by the authors. Licensee MDPI, Basel, Switzerland. This article is an open access article distributed under the terms and conditions of the Creative Commons Attribution (CC BY) license (https:// creativecommons.org/licenses/by/ $4.0 /)$.

\begin{abstract}
The sodium-activated potassium channel Slack $\left(\mathrm{K}_{\mathrm{Na}} 1.1\right.$, Slo2.2, or Kcnt1) is highly expressed in populations of sensory neurons, where it mediates the sodium-activated potassium current $\left(\mathrm{I}_{\mathrm{KNa}}\right)$ and modulates neuronal activity. Previous studies suggest that Slack is involved in the processing of neuropathic pain. However, mechanisms underlying the regulation of Slack activity in this context are poorly understood. Using whole-cell patch-clamp recordings we found that Slack-mediated $\mathrm{I}_{\mathrm{KNa}}$ in sensory neurons of mice is reduced after peripheral nerve injury, thereby contributing to neuropathic pain hypersensitivity. Interestingly, Slack is closely associated with ATP-sensitive P2X3 receptors in a population of sensory neurons. In vitro experiments revealed that Slack-mediated $\mathrm{I}_{\mathrm{KNa}}$ may be bidirectionally modulated in response to P2X3 activation. Moreover, mice lacking Slack show altered nocifensive responses to P2X3 stimulation. Our study identifies $\mathrm{P} 2 \mathrm{X} 3$ /Slack signaling as a mechanism contributing to hypersensitivity after peripheral nerve injury and proposes a potential novel strategy for treatment of neuropathic pain.
\end{abstract}

Keywords: Slack; P2X3; dorsal root ganglia; neuropathic pain; mice

\section{Introduction}

Neuropathic pain resulting from a lesion or disease of the nervous system affects $6.9-10 \%$ of the general population [1]. It is poorly managed by existing analgesic drugs, with less than half of patients achieving satisfactory pain relief [2]. Therefore, determining the molecular constituents of neuropathic pain processing remains an important endeavor of pain research [3-5].

The transmission and processing of pain rely critically on the activities of ion channels that are expressed in sensory neurons. Over the past few years, several ion channel subtypes have been implicated in pain signaling and are being pursued as novel targets for analgesic therapy [6]. Among the potential targets for treatment of neuropathic pain, the sodium $\left(\mathrm{Na}^{+}\right)$-dependent potassium $\left(\mathrm{K}^{+}\right)$channel Slack (also termed $\mathrm{K}_{\mathrm{Na}} 1.1$, Slo2.2, or Kcnt1) has gained recent interest. Slack is only weakly voltage-dependent and activated by intracellular $\mathrm{Na}^{+}$[7-10], whereas its activity is inhibited by divalent cations that modify channel gating by an allosteric mechanism [11]. Slack is highly expressed in the isolectin B4 (IB4)-binding, non-peptidergic subpopulation of $C$ fiber sensory neurons, and accumulating evidence implicates Slack in the processing of pain [12-19].

In a previous study, we generated Slack mutant mice and observed increased pain hypersensitivity of global and sensory neuron-specific Slack knockouts in models of neuropathic pain [15]. By contrast, their behavior in models of inflammatory and acute 
nociceptive pain was normal $[15,18]$, suggesting a specific function of Slack in neuropathic pain processing. However, the mechanisms that regulate Slack activity in neuropathic pain remain elusive.

Here, we further characterized the functions of Slack in pain processing. We report that the potassium currents generated by Slack in non-peptidergic $C$ fiber sensory neurons are diminished after peripheral nerve injury. Furthermore, we provide evidence that Slack is closely associated with ATP-sensitive P2X3 receptors, which are highly expressed in nonpeptidergic $C$ fiber sensory neurons and play an important role in peripheral sensitization during chronic pain (for review, see [20,21]. Our data suggest that a P2X3-mediated ion influx modulates the activity of Slack and thus regulates neuropathic pain sensitivity.

\section{Results}

\subsection{Slack ${ }^{-1}$ Mice Show Increased Neuropathic Pain Behavior after Peripheral Nerve Injury}

To evaluate the role of Slack in neuropathic pain processing, we exposed Slack ${ }^{-/-}$and wide-type (WT) mice to the spared nerve injury (SNI) model of experimental neuropathy, wherein the tibial and common peroneal nerves are ligated and transected while the sural nerve is left intact. Thirteen days after SNI, both genotypes developed mechanical hypersensitivity in the lateral hind paw region (innervated by the spared sural nerve), as indicated by decreases in mechanical thresholds in the von Frey test (Figure 1A). Notably, the extent of SNI-induced mechanical hypersensitivity was markedly increased in Slack $^{-/-}$mice as compared to WT littermates (Figure 1A). These data confirm our findings in an earlier study, in which the mechanical hypersensitivity was measured using another method (Dynamic Plantar Aesthesiometer [15]). In addition, we assessed non-reflexive pain behavior using a dynamic weight-bearing device. As shown in Figure 1B, weight bearing on the ipsilateral hind paw was reduced after SNI in both genotypes. However, the weight-bearing reduction was more pronounced in Slack ${ }^{-/-}$mice as compared to WT littermates, indicating an increased neuropathic pain behavior in the absence of Slack. Furthermore, control experiments in dorsal root ganglia (DRGs) of naive WT and Slack ${ }^{-/-}$ mice revealed similar mRNA expression levels of related potassium channels (Supplementary Figure S1A) and a similar percentage of DRG neuron populations positive for standard markers (Supplementary Figure S1B) in both genotypes, suggesting that there were no general impairments that might account for the observed behavioral phenotype in Slack $^{-/-}$mice. Together, these data support an inhibitory role for Slack in the modulation of neuropathic pain.

\section{A}

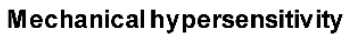

\section{B Dynamic Weight Bearing}
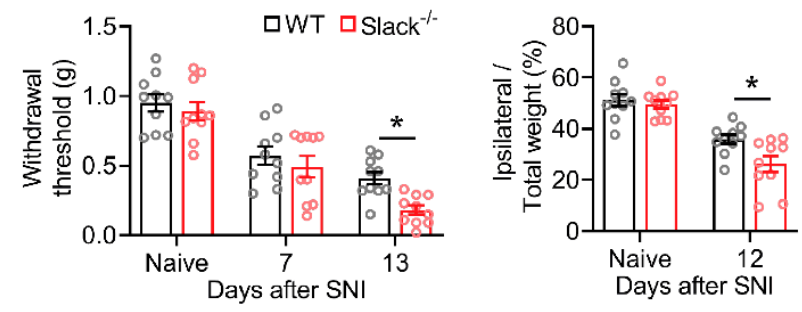

Figure 1. Neuropathic pain behavior is increased in Slack ${ }^{-/-}$mice. (A) paw withdrawal latencies of Slack $^{-/-}$and wild-type (WT) mice after mechanical stimulation with von Frey filaments (up-anddown method) in the spared nerve injury (SNI) model of neuropathic pain ( $n=10$ animals per group). Thirteen days after SNI, Slack ${ }^{-/-}$mice showed increased mechanical hypersensitivity compared to WT littermates (two-way ANOVA; $p=0.0312$; WT versus Slack ${ }^{-/}$). (B) percentage of weight bearing on the ipsilateral hind paw relative to both hind paws in Slack ${ }^{-/}$and WT mice $(n=10$ animals per group), as assessed using a dynamic weight-bearing device. Twelve days after SNI, the weight-bearing reduction was more pronounced in Slack ${ }^{-/-}$mice compared to WT littermates (two-way ANOVA; $p=0.0464$; WT versus Slack ${ }^{-/}$) Bars denote mean \pm SEM. ${ }^{*} p<0.05$. 


\subsection{Slack-Mediated Potassium Currents in Sensory Neurons are Reduced after Nerve Injury}

In an earlier study we demonstrated that Slack is highly expressed in DRG neurons and that the vast majority (86.5\%) of Slack-positive cells bind IB4, whereas $12.6 \%$ are positive for calcitonin gene-related peptide (CGRP), two markers of non-peptidergic and peptidergic $C$ fiber sensory neurons, respectively [15]. Moreover, Slack has been shown to generate a sodium-activated outward potassium current $\left(\mathrm{I}_{\mathrm{KNa}}\right)$ in whole-cell voltage-clamp recordings on IB4-positive sensory neurons of naive mice [15,18,22]. To examine whether Slack-mediated $\mathrm{I}_{\mathrm{KNa}}$ is altered after peripheral nerve injury, we performed whole-cell patchclamp recordings on IB4-positive sensory neurons of WT and Slack ${ }^{-/-}$mice 14-19 days after SNI. At a holding potential of $-70 \mathrm{mV}$, a series of $500 \mathrm{~ms}$-long test pulses ranging from -120 to $+120 \mathrm{mV}$ in intervals of $20 \mathrm{mV}$ were applied in the presence of $140 \mathrm{mM}$ extracellular $\mathrm{NaCl}$. In sensory neurons of WT mice, the amplitude of the total outward $\mathrm{K}^{+}$ current $\left(\mathrm{I}_{\mathrm{K}}\right)$ was significantly reduced after the nerve injury compared to the non-injured control (Figure 2A,B). By contrast, the $\mathrm{I}_{\mathrm{K}}$ amplitude in sensory neurons of Slack ${ }^{-/-}$mice was at the level of WT mice post-SNI and not altered by SNI (Figure 2A,B). Moreover, under $\mathrm{Na}^{+}$-free conditions (i.e., after replacement of $\mathrm{NaCl}$ with choline chloride in the external solution) the $\mathrm{I}_{\mathrm{K}}$ amplitude was similar in all groups (Figure $\left.2 \mathrm{C}, \mathrm{D}\right)$. These data suggest that Slack-mediated $\mathrm{I}_{\mathrm{KNa}}$ in IB4-positive sensory neurons is reduced after peripheral nerve injury, thereby contributing to neuropathic pain hypersensitivity.

\subsection{Unaltered Slack Expression in DRGs and the Spinal Cord after Spared Nerve Injury}

We next asked whether a downregulation of Slack expression in sensory neurons might underlay the reduced $\mathrm{I}_{\mathrm{KNa}}$ after SNI in WT mice, because various potassium channels are downregulated at the transcriptional level during neuropathic pain [6]. However, immunostaining experiments using a specific anti-Slack antibody, whose immunoreactivity is absent in tissues from Slack ${ }^{-/-}$mice [15] and that does not cross-react with the closely related potassium channel Slick [18], showed that the percentage of Slack-immunoreactive sensory neurons was indistinguishable in DRGs of naive mice and 14 days after SNI (Figure 3A,B). Similarly, quantitative real-time reverse transcription PCR (qRT-PCR) analyses revealed unaltered Slack mRNA expression in lumbar DRGs 7 and 14 days after SNI (Figure 3C). Moreover, Slack immunoreactivity in the ipsilateral and contralateral dorsal horn of the lumbar spinal cord, in which the central terminals of sensory neurons terminate, was similar 14 days after SNI (Figure 3D). Accordingly, Western blot analyses of spinal cord tissue extracts did not detect any alteration of Slack expression in naive and post-SNI animals (Figure 3E,F). These data suggest that the expression of Slack channels, unlike many other potassium channels, is unaltered in sensory neurons in response to peripheral nerve injury.

\subsection{Slack Channels Colocalize with P2X3 Receptors in Sensory Neurons}

The unaltered Slack expression after SNI points to inhibition of Slack channel activity underlying the reduced $\mathrm{I}_{\mathrm{KNa}}$ after peripheral nerve injury. Because Slack channels are inhibited by intracellular $\mathrm{Ca}^{2+}$ and other divalent cations [11], we speculated that $\mathrm{Ca}^{2+}$ permeable ion channels in proximity to Slack channels might mediate the inhibition of $\mathrm{I}_{\mathrm{KNa}}$ in sensory neurons after nerve injury. Given the enriched expression of Slack in IB4-positive sensory neurons $[15,23]$ and its functional contribution to neuropathic pain processing, we hypothesized several reasons why Slack might interact with the ATP receptor subunit P2X3: (i) P2X3 receptors, like Slack, are almost exclusively expressed in IB4-positive sensory neurons [24], (ii) they are permeable for $\mathrm{Ca}^{2+}, \mathrm{Na}^{+}$, and other cations, and (iii) signaling through P2X3 receptors essentially contributes to neuropathic pain hypersensitivity [25-28]. As shown in Figure 4A-C, the co-localization of Slack and P2X3 in DRG neurons is almost complete, as $97.1 \%$ of Slack-positive DRG neurons co-stained with P2X3 and $94.6 \%$ of P2X3-positive DRG neurons co-stained with Slack. Control experiments confirmed that almost all P2X3-positive DRG neurons bind IB4 (Figure S2C), suggesting that the anti$\mathrm{P} 2 \mathrm{X} 3$ antibody used in our immunostaining experiment is specific. Furthermore, Slack 
and P2X3 are also highly co-localized in the dorsal horn of the spinal cord (Figure 4D). Moreover, Western blot control experiments demonstrated similar P2X3 protein levels in DRGs and the spinal cord of Slack ${ }^{-1-}$ and WT mice (Figure 4E,F) and P2X3 immunostaining detected a similar percentage of P2X3-positive DRG neurons in both genotypes (Figure 4G), suggesting that there was no compensatory regulation due to the Slack knockout that might have contributed to the observed pain behavior and neuronal potassium currents in Slack ${ }^{-/-}$mice. Together, these findings point to a possible interaction of Slack and P2X3 in sensory neurons.

A

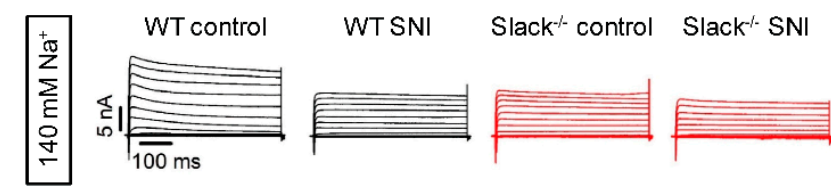

B

๑ WT control $\bullet$ WT SNI $\quad$ o Slack $^{-/-}$control $\bullet$ Slack $^{-1-}$ SNI
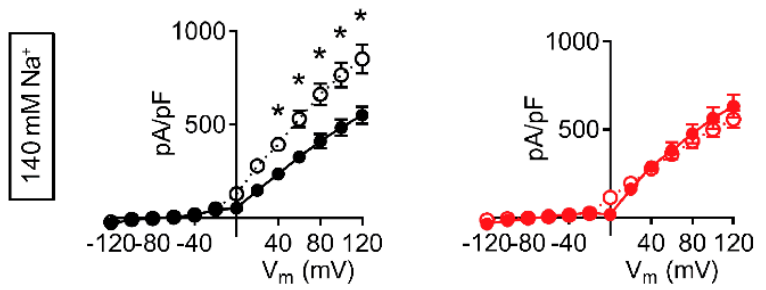

C

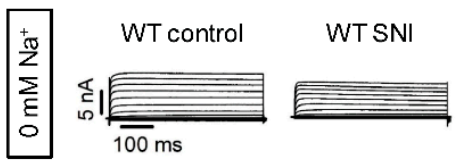

Slack ${ }^{-1}$ control Slack ${ }^{-1}$ SNI

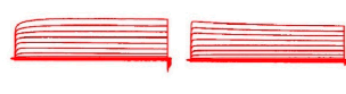

D
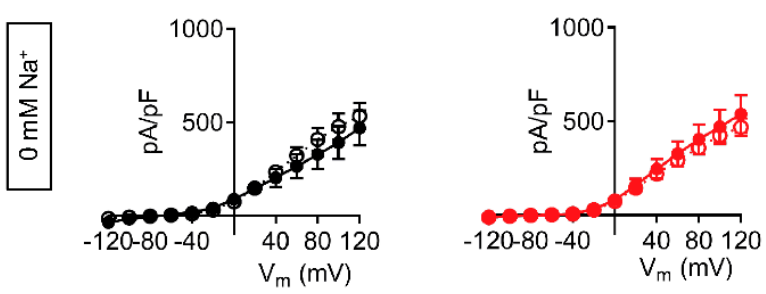

Figure 2. Slack-mediated potassium currents in sensory neurons are reduced after SNI. (A,B) Representative outward $\mathrm{K}^{+}$current $\left(\mathrm{I}_{\mathrm{K}}\right)$ traces $(\mathbf{A})$ and associated current-voltage $(\mathrm{I}-\mathrm{V})$ curves $(\mathbf{B})$ from whole-cell voltage recordings on IB4-positive lumbar (L4-L5) dorsal root ganglion (DRG) neurons of WT (black) and Slack ${ }^{-/-}$mice (red) 14-19 days after spared nerve injury (SNI). Contralateral DRG neurons were used as control. Recordings shown in (A) and (B) were performed in the presence of $140 \mathrm{mM} \mathrm{NaCl}$ in the external solution, i.e., under physiological conditions. $n=21-29$ cells per group. Repeated ANOVA measures followed by Fisher's Least Significant Difference test; WT control versus WT SNI: $p=0.0062$; Slack ${ }^{-/-}$control versus Slack ${ }^{-/-}$SNI: $p=0.4374$. (C,D) Representative $\mathrm{I}_{\mathrm{K}}$ traces (C) and associated I-V curves (D) in the same experimental setting as shown in (A) and (B), however, after replacement of $\mathrm{NaCl}$ by $140 \mathrm{mM}$ choline chloride in the external solution to obtain $\mathrm{Na}^{+}$-free conditions. $n=7-9$ cells per group. Repeated ANOVA measures: WT control versus WT SNI: $p=0.1825$; Slack ${ }^{-/-}$control versus Slack ${ }^{-/-}$SNI: $p=0.6125$. The data show that $\mathrm{Na}^{+}$-activated $\mathrm{I}_{\mathrm{K}}$ $\left(\mathrm{I}_{\mathrm{KNa}}\right)$ in sensory neurons is carried by Slack channels and reduced after SNI. Data in $(\mathbf{B})$ and (D) are mean \pm SEM. ${ }^{*} p<0.05$. 


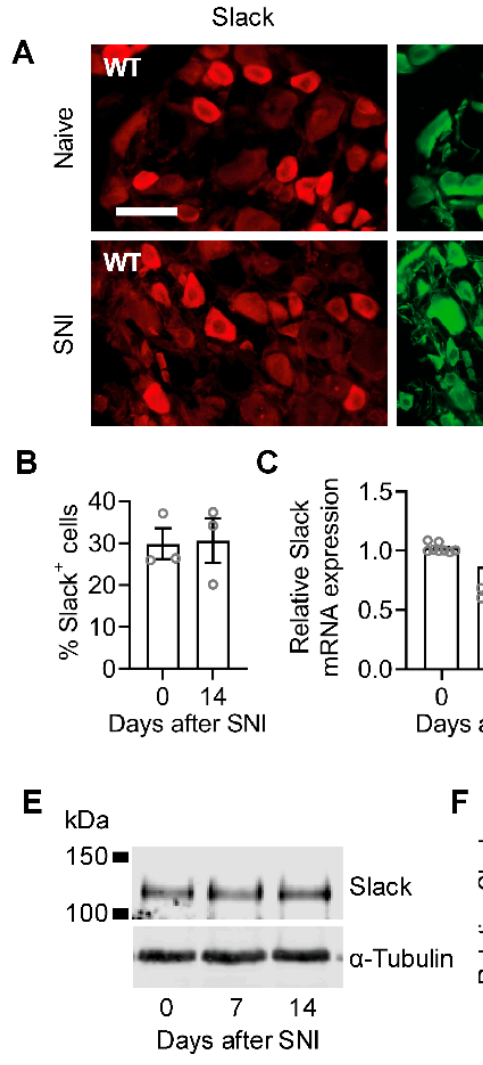

TUBB3
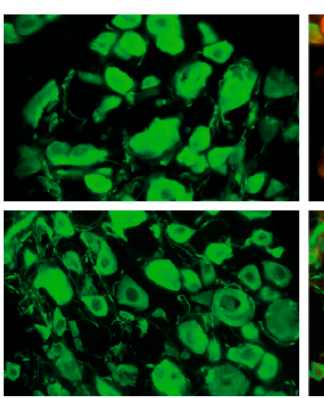

D
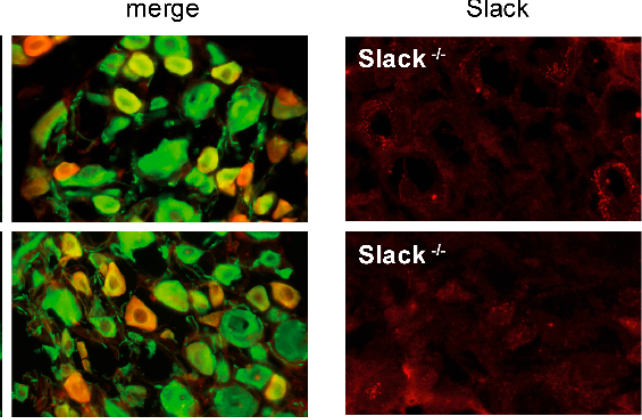

\section{Slack $^{-1}$}

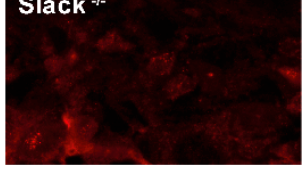

Contralateral
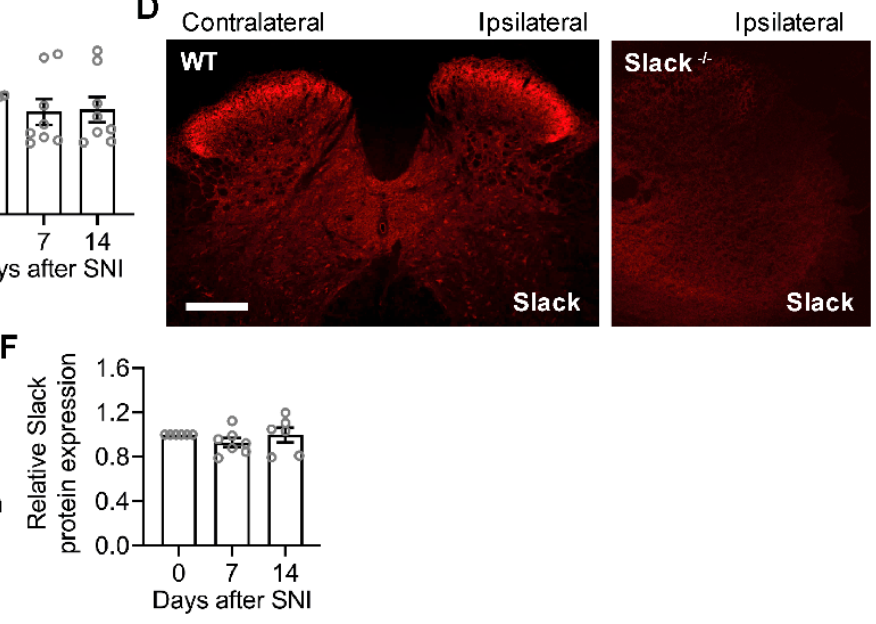

Figure 3. Unaltered Slack expression in WT mice after peripheral nerve injury. (A,B) Double-labeling immunostaining of Slack and the neuronal marker anti- $\beta$ III-tubulin (TUBB3) in DRGs of naive WT mice and 14 days after SNI. Colocalization of Slack and TUBB3 appears in yellow. The staining suggests that Slack is exclusively localized to neurons and that its

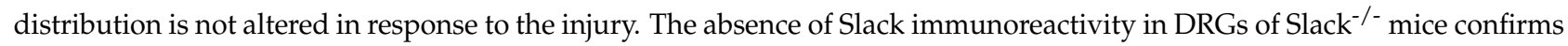
the antibody specificity (A). The percentage of Slack-immunoreactive DRG neurons of all $\beta$ III-tubulin-stained neurons is similar in naive mice and 14 days after SNI ((B); 1833 and 1630 cells counted, respectively; $n=3$ mice per group). Student's t-test: $p=0.9130$. (C), Quantitative RT-PCR experiments showed that Slack mRNA levels are not altered in DRGs 7 or 14 days after SNI as compared to naive control animals ( $n=8$ mice per group). One-way ANOVA: $p=0.1433$. (D), Immunostaining in the lumbar spinal cord of WT mice $14 \mathrm{~d}$ after SNI shows similar Slack expression in the ipsilateral and contralateral dorsal horn. The absence of Slack immunoreactivity in the spinal cord of Slack ${ }^{-/-}$mice confirms the antibody specificity. (E,F) A Western blot of spinal cord extracts shows similar Slack protein $(140 \mathrm{kDa})$ expression in naive mice and 7 or 14 days after SNI surgery (E). Uncropped original image is shown in Figure S2A. Quantification is shown in (F). Alpha-tubulin was used as a loading control. One-way ANOVA: $p=0.4446$. Bars denote mean \pm SEM. Scale bars: $50 \mu \mathrm{m}($ A), $200 \mu \mathrm{m}$ (D).

\subsection{P2X3 Activation Modulates Slack-Mediated Potassium Currents In Vitro}

We next studied the functional properties of co-expressed recombinant Slack and P2X3 receptors. For that purpose, we used a commercially available HEK-293 cell line stably expressing human Slack channels (herein referred to as HEK-Slack cells) and transiently transfected GFP-tagged human P2X3 receptors into these cells. This strategy led to expression of $\mathrm{P} 2 \mathrm{X} 3$ in about $40 \%$ of transfected cells (as indicated by green fluorescence in microscopy; the resulting P2X3-positive cells were referred to as HEK-Slack-P2X3 cells). We performed whole-cell patch-clamp recordings at a holding potential of $-70 \mathrm{mV}$ by applying series of $500 \mathrm{~ms}$-long test pulses ranging from -120 to $+120 \mathrm{mV}$ in intervals of $20 \mathrm{mV}$. A first series of experiments were conducted using a physiological external solution (i.e., in the presence of $140 \mathrm{mM} \mathrm{NaCl}, 5 \mathrm{mM} \mathrm{KCl}, 2 \mathrm{mM} \mathrm{CaCl}_{2}, 2 \mathrm{mM} \mathrm{MgCl}_{2}$, and $10 \mathrm{mM}$ HEPES). As shown in Figure 5A-C, outward potassium currents $\left(\mathrm{I}_{\mathrm{K}}\right)$ were detected in both HEK-Slack and HEK-Slack-P2X3 cells. Interestingly however, the addition of the P2X3 agonist $\alpha, \beta$-meATP (30 $\mu \mathrm{M}$ [29]) to the external solution reduced $\mathrm{I}_{\mathrm{K}}$ in HEK-Slack-P2X3 
cells (Figure 5B,C) but not in HEK-Slack cells (Figure 5A). These results imply that P2X3 activation, which in our experimental setting may result in an influx of $\mathrm{Na}^{+}, \mathrm{Mg}^{2+}$, and $\mathrm{Ca}^{2+}[30,31]$, is associated with inhibition of Slack activity.

A recent study revealed that Slack activity is inhibited by divalent cations [11]. We reasoned that the observed reduction of $\mathrm{I}_{\mathrm{K}}$ in the presence of the P2X3 agonist might be mediated mainly by $\mathrm{Ca}^{2+}$, because $\mathrm{Mg}^{2+}$ represents a much weaker Slack inhibitor than $\mathrm{Ca}^{2+}[11]$. To test this hypothesis, we performed experiments under $\mathrm{Ca}^{2+}$-free conditions, i.e., after replacement of $\mathrm{Ca}^{2+}$ in the external solution by $\mathrm{Mg}^{2+}$. Strikingly, in the absence of $\mathrm{Ca}^{2+} \alpha, \beta$-meATP increased $\mathrm{I}_{\mathrm{K}}$ in HEK-Slack-P2X3 cells but not in HEK-Slack cells (Figure 5D-F). We assumed that the increased $\mathrm{I}_{\mathrm{K}}$ was attributed to an exaggerated, $\mathrm{Na}^{+}-$ mediated activation of Slack channels due to the lack of inhibition by $\mathrm{Ca}^{2+}$. Altogether, these data suggest that Slack-mediated $\mathrm{I}_{\mathrm{KNa}}$ may be bidirectionally modulated by a P2X3driven ion influx.

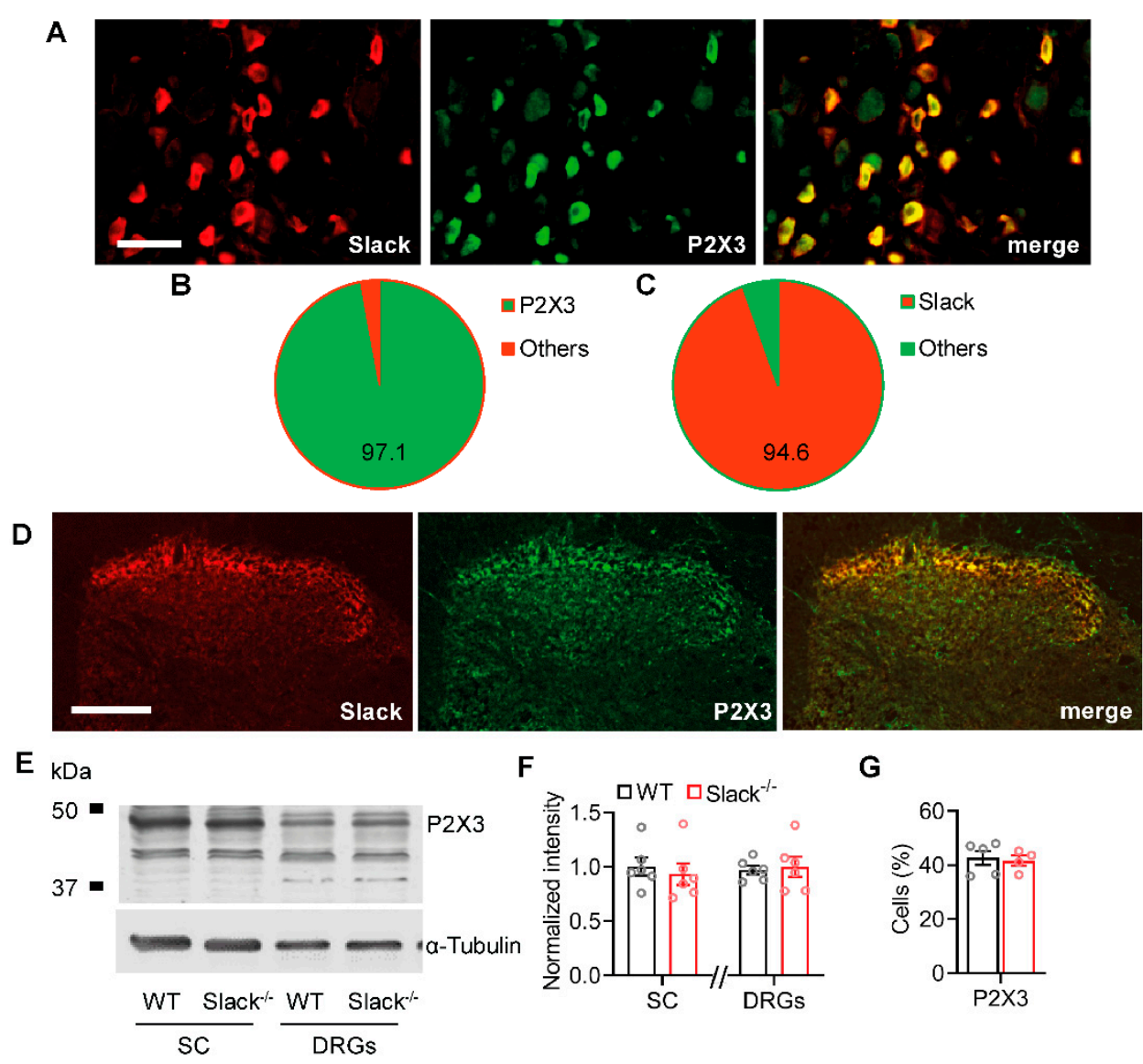

Figure 4. Slack channels co-localize with P2X3 receptors in sensory neurons. (A-C) Double-labeling immunostaining of Slack and P2X3 in sensory neurons (A) revealed that $97.1 \% \pm 0.2 \%$ of Slackpositive DRG neurons co-stained with P2X3 ((B); 1203 cells counted, $n=3$ mice) and that $94.6 \% \pm$ $2.0 \%$ of P2X3-positive DRG neurons co-stained with Slack ((C); 1203 cells counted, $n=3$ mice). (D) Double-labeling immunostaining of Slack and P2X3 in the spinal cord indicates a high degree of co-localization in the superficial dorsal horn. (E,F) Western blot of P2X3 in spinal cord (SC) and DRGs from WT and Slack ${ }^{-/-}$mice demonstrates identical abundance of P2X3 in both genotypes. The uncropped original image is shown in Figure S2B. Student's t-test: $p=0.5986$ in the spinal cord and $p=0.7631$ in DRGs. Alpha-tubulin was used as a loading control. (G) Immunostaining revealed that the percentage of DRG neurons positive for P2X3 is similar in WT and Slack ${ }^{-/-}$mice. Student's t-test: $p=0.4046$. Bars denote mean \pm SEM. Scale bars: $50 \mu \mathrm{m}(\mathbf{A})$ and $100 \mu \mathrm{m}$ (D). 


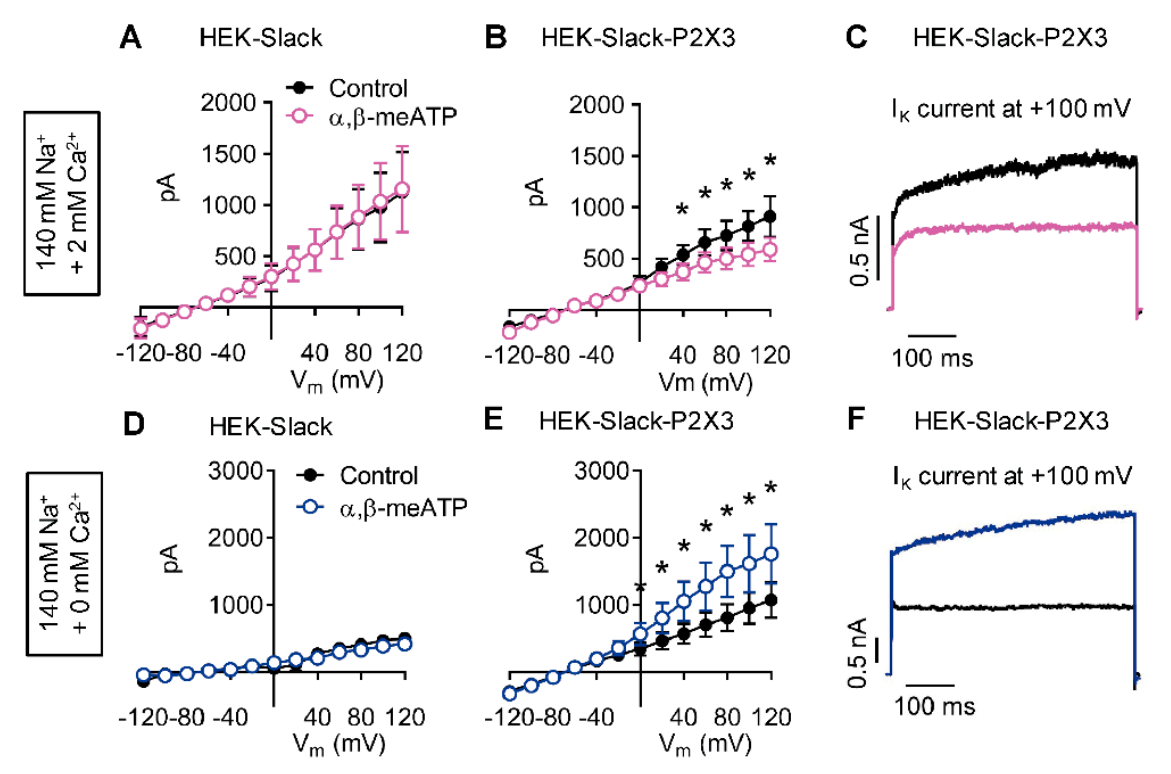

Figure 5. Slack-mediated potassium currents are altered by P2X3 activation in vitro. Representative $\mathrm{I}_{\mathrm{K}}$ traces from whole-cell voltage-clamp recordings on HEK-Slack and HEK-Slack-P2X3 cells are shown. The current traces presented in $(\mathrm{A}-\mathrm{C})$ were recorded in the presence of $2 \mathrm{mM} \mathrm{CaCl}_{2}$ in the external solution ( $n=9-10$ cells per group), whereas those depicted in (D-F) were recorded after the replacement of $\mathrm{CaCl}_{2}$ by $\mathrm{MgCl}_{2}$ ( $n=5-8$ cells per group). Experiments were performed without (control) or with the addition of the P2X3 agonist $\alpha, \beta$-methylene ATP $(\alpha, \beta$-meATP; $30 \mu \mathrm{M})$ to the external solution. Note that the P2X3 agonist exerted opposite effects in HEK-Slack-P2X3 cells dependent on the $\mathrm{Ca}^{2+}$ concentration: $\alpha, \beta$-meATP reduced $\mathrm{I}_{\mathrm{K}}$ in the presence of $\mathrm{Ca}^{2+}$, whereas it increased $\mathrm{I}_{\mathrm{K}}$ under $\mathrm{Ca}^{2+}$-free conditions. Data are shown as mean $\pm \mathrm{SEM}$. Student's t-test, ${ }^{*} p<0.05$.

\subsection{P2X3-Mediated $\mathrm{Ca}^{2+}$ Influx Is Unaltered in Sensory Neurons of Slack ${ }^{-1-}$ Mice}

We next investigated the Slack-P2X3 interaction in sensory neurons. To exclude the possibility that a $\mathrm{P} 2 \mathrm{X} 3$-driven $\mathrm{Ca}^{2+}$ influx in sensory neurons might be generally altered by Slack deficiency, we performed control experiments to analyze the $\alpha, \beta$-meATPevoked $\mathrm{Ca}^{2+}$ influx in sensory neurons of WT and Slack ${ }^{-/-}$mice. Calcium imaging in cultured lumbar DRG neurons of WT and Slack ${ }^{-/-}$mice revealed that incubation with $\alpha, \beta$-meATP $(30 \mu \mathrm{M}$ [32]) evoked a similar calcium influx in both genotypes (Figure $6 \mathrm{~A}$ ). The magnitude of the $\mathrm{Ca}^{2+}$ response (Figure $6 \mathrm{~B}, \mathrm{C}$ ) and the proportion of responsive DRG neurons (Figure 6D) were comparable in DRG neurons of WT and Slack ${ }^{-/-}$mice. These data confirm that Slack deficiency per se does not affect the P2X3-mediated $\mathrm{Ca}^{2+}$ influx in sensory neurons.

\subsection{P2X3-Mediated Pain Behavior Is Altered in Slack ${ }^{-1}$ Mice}

We then assessed a functional P2X3/Slack interaction in behavioral experiments in vivo. We injected $\alpha, \beta$-meATP (12 nmol [26]) into a hind paw of naive WT and Slack ${ }^{-/-}$ mice and analyzed the resulting paw-licking response over $10 \mathrm{~min}$. Of note, during the first $2 \mathrm{~min}$, the paw licking induced by $\alpha, \beta$-meATP was significantly increased in Slack ${ }^{-/}$ mice as compared to WT mice (Figure 7A). Virtually no paw licking was observed at later time points $(2-10 \mathrm{~min}$ ) in both genotypes (Figure $7 \mathrm{~A}$ ), confirming earlier reports that the immediate nocifensive response to intraplantar $\alpha, \beta$-meATP is relatively short-lived in naive animals [27]. After pretreatment with the selective P2X3 receptor antagonist AF353 (70 nmol intraplantar [33,34]) 10 min prior to the $\alpha, \beta$-meATP injection, the pawlicking response was reduced, and no significant differences between groups were detected (Figure 7B). A similar paw-licking behavior occurred after injection of the vehicle $(0.9 \%$ $\mathrm{NaCl}$; Figure 7C), suggesting that the behavioral responses to the $\alpha, \beta$-meATP injection shown in Figure 7A were mediated by $\mathrm{P}_{2} \mathrm{X}_{3}$ receptors. These data indicate that Slack 
channels control the immediate pronociceptive effects of $\mathrm{P} 2 \mathrm{X}_{3}$ receptor activation in naive mice in vivo.

A
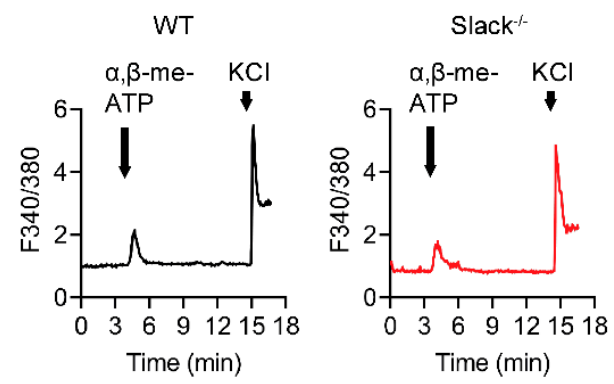

B

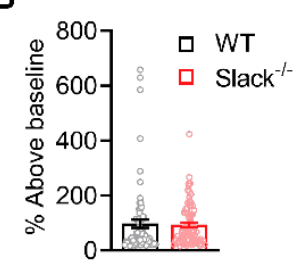

C

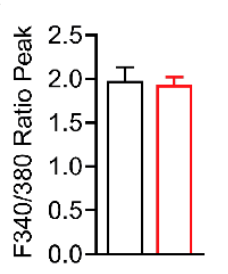

D

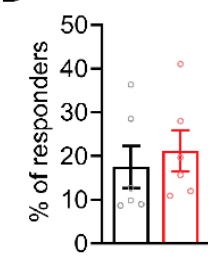

Figure 6. $\mathrm{P} 2 \mathrm{X} 3$-mediated $\mathrm{Ca}^{2+}$ traces are normal in sensory neurons of Slack ${ }^{-/-}$mice. (A) Representative examples of Fura-2 ratiometric $\mathrm{Ca}^{2+}$ traces in DRG neurons of WT and Slack ${ }^{-/-}$mice evoked by $\alpha$, $\beta$-meATP (30 $\mu \mathrm{M}, 30 \mathrm{~s}$ application) and $\mathrm{KCl}(75 \mathrm{mM}, 20 \mathrm{~s}$ application). Responses to $\mathrm{KCl}$ were used to test neuron viability. Experiments were performed in lumbar (L4-L5) DRG neurons ( $n=402-518$ neurons per group). (B,C) Quantification of the magnitude of the $\mathrm{Ca}^{2+}$ response to $\alpha, \beta$-meATP stimulation with percentage above baseline $((\mathbf{B}) p=0.7858)$ and ratio peak $((\mathbf{C}) p=0.7858)$. (D) Quantification of the percentage of responsive neurons to $\alpha, \beta$-meATP stimulation $(p=0.5966)$. The data show that $\alpha, \beta$-meATP-evoked $\mathrm{Ca}^{2+}$ responses are similar in DRG neurons from Slack ${ }^{-/-}$and WT mice. Bars denote mean \pm SEM and circles show data from each neuron in (B) and from each mouse in (D). Student's t-tests were performed.

We next analyzed the P2X3/Slack interaction during neuropathic pain using the SNI model. For that purpose, $\alpha, \beta$-meATP $(12 \mathrm{nmol})$ was injected into the dorsolateral region of the ipsilateral hind paw 2-3 weeks after SNI. As shown in Figure 7D, in WT mice the paw-licking response after injection of $\alpha, \beta$-meATP persisted over the 10 min observation period, which is in line with the sensitization of P2X3 receptors after traumatic injury that was reported in previous studies $[26,27,35]$. In Slack ${ }^{-/-}$mice, the paw-licking response was increased compared to WT mice in the first $2 \mathrm{~min}$ (with a similar licking time as observed in naive mice, see Figure 7A). During 2-6 min after the injection, the licking response was similar in Slack ${ }^{-/-}$and WT mice (and increased compared to naive mice, see Figure 7A), pointing to a sensitization of $\mathrm{P} 2 \mathrm{X} 3$ receptors in both genotypes. Interestingly however, at late stages $(6-10 \mathrm{~min})$ the paw licking in Slack ${ }^{-/-}$mice was lower than in WT mice (Figure 7D). These data suggest that Slack facilitates the P2X3 receptor sensitization at late stages, which is in accordance with a $\mathrm{Ca}^{2+}$-driven inhibition of Slack channel activity in vivo. 

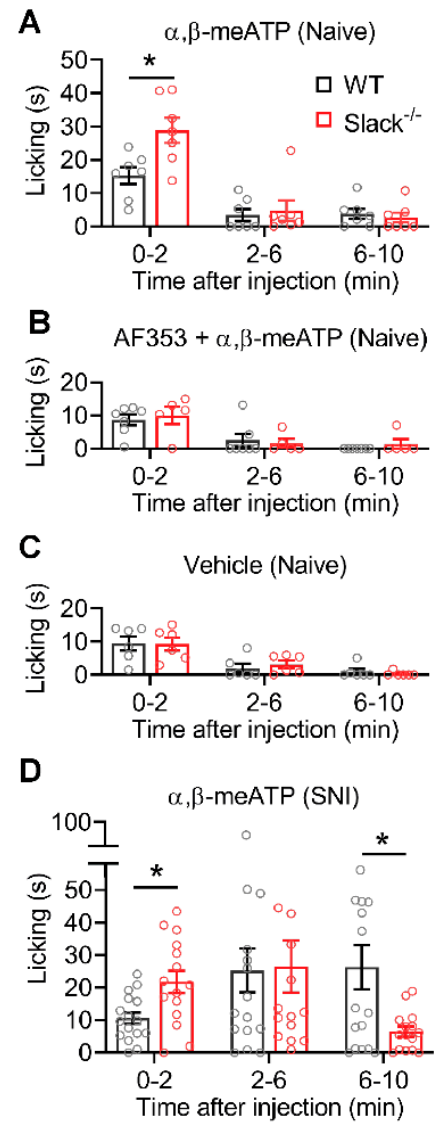

Figure 7. P2X3-dependent nocifensive behavior is altered in Slack ${ }^{-/-}$mice. Paw-licking responses induced by paw injection of drugs are shown. (A) The immediate paw licking in the first $2 \mathrm{~min}$ after injection of $\alpha, \beta$-meATP (12 nmol) is increased in naive Slack ${ }^{-/-}$mice compared with WT mice ( $n=7$ /genotype; $p=0.0398$ in $0-2 \mathrm{~min} ; p=0.9800$ in $2-6 \mathrm{~min} ; p=0.9352$ in $6-10 \mathrm{~min}$ ). (B) No significant differences between groups occurred when the P2X3 receptor antagonist AF353 (70 nmol intraplantar) was injected $10 \mathrm{~min}$ prior to $\alpha, \beta$-meATP $(n=5-7 /$ genotype; $p=0.9664$ in $0-2 \mathrm{~min} ; p=$ 0.9732 in 2-6 $\mathrm{min} ; p=0.7546$ in 6-10 $\mathrm{min}$ ). (C) Paw-licking responses after injection of the vehicle were comparable in Slack ${ }^{-/}$and WT mice $(n=6 /$ genotype; $p=0.9999$ in 0-2 min; $p=0.8934$ in 2-6 min; $p$ $=0.8709$ in $6-10 \mathrm{~min}$ ) and similar to the licking behavior after combined injection of $\alpha, \beta$-meATP and AF353 (B). (D) When $\alpha, \beta$-meATP $(12 \mathrm{nmol})$ was injected in the ipsilateral hind paw after SNI, the paw-licking response persisted over the $10 \mathrm{~min}$ observation period in WT mice. In Slack $\mathrm{C}^{-/-}$mice, the paw licking was increased in the first 2 min and decreased from 6-10 min compared with WT mice $(n$ $=16 /$ genotype; $p=0.0262$ in $0-2 \mathrm{~min} ; p=0.9993$ in $2-6 \mathrm{~min}$; and $p=0.0362$ in $6-10 \mathrm{~min}$ ). Two-way ANOVA tests were performed. Bars denote mean \pm SEM. ${ }^{*} p<0.05$.

\section{Discussion}

Here, we provide further support that Slack plays an important role in neuropathic pain processing. We uncovered Slack/P2X3 signaling as a new mechanism contributing to neuropathic pain processing. Strikingly, our data suggest that activation of P2X3 receptors may both activate and inhibit Slack, depending on P2X3 ion permeability. The main findings from this study are highlighted in a schematic diagram in Figure 8. Collectively, these data add to the complexity of ion channel regulation in sensory neurons during persistent pain. 

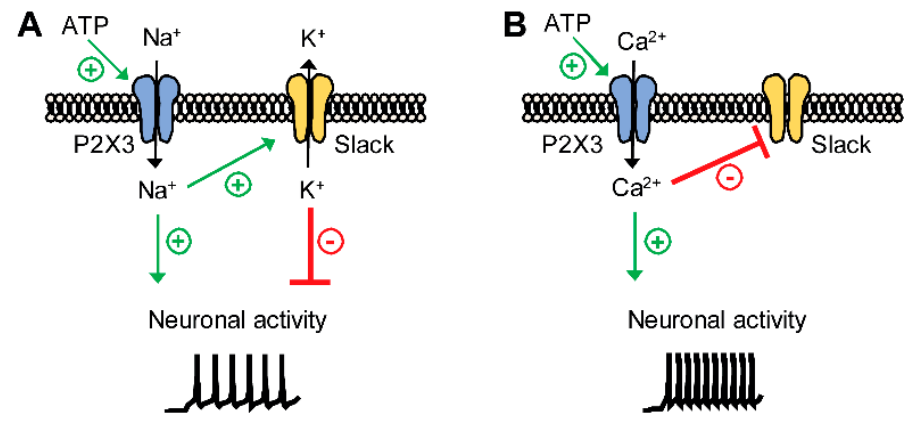

Figure 8. Proposed model demonstrating the functional coupling of Slack channels and P2X3 receptors in IB4-positive sensory neurons. Activation of P2X3 receptors by ATP may lead to an influx of $\mathrm{Na}^{+}, \mathrm{Ca}^{2+}$, or both into sensory neurons. (A) P2X3-mediated $\mathrm{Na}^{+}$influx activates Slack, which results in $\mathrm{K}^{+}$efflux and thus partial inhibition of neuronal activity. (B) P2X3-mediated $\mathrm{Ca}^{2+}$ influx inhibits Slack, which leads to increased neuronal activity due to the lack of inhibition.

Slack channels are widely distributed in the central and peripheral nervous systems. Previous studies detected particularly high Slack expression levels in IB4-positive, nonpeptidergic sensory neurons $[14,15,23,36]$, and behavioral analyses of global and sensory neuron-specific Slack knockout mice uncovered an inhibitory function of Slack in the processing of neuropathic pain [15]. These observations are further supported by a recent clinical trial using the Slack activator loxapine [19], pointing to Slack as a potential novel target to alleviate chronic pain in humans. We here confirm that Slack modulates neuropathic pain processing, because Slack ${ }^{-/-}$mice demonstrated an increased mechanical hypersensitivity (assessed using von Frey filaments) and a decreased weight distribution on the ipsilateral hind paw (assessed using dynamic weight bearing) after peripheral nerve injury.

Our data further expand the role of Slack in neuropathic pain by demonstrating that $\mathrm{I}_{\mathrm{KNa}}$ in IB4-positive sensory neurons, which is mainly driven by Slack, is reduced after peripheral nerve injury. In general, under neuropathic pain conditions there is a reduction in the expression of several subtypes of potassium channels that gives rise to hyperexcitability [6,37]. Prominent examples of downregulated potassium channels in DRG neurons after peripheral nerve injury include Kv9.1 [3,38], Kv1.1, and Kv1.2 [39,40]. Our observation that, unlike these channels, Slack expression in DRGs and the spinal cord is not altered after peripheral nerve injury further supports the idea that Slack might be a target for pain therapy.

Our study uncovered P2X3 as a previously unrecognized signaling pathway that regulates Slack activity. Previously identified $\mathrm{Na}^{+}$-permeable ion channels that may activate Slack include AMPA receptors [41] and $\mathrm{Na}_{\mathrm{v}} 1.8$ channels [22]. It has been shown that $\mathrm{Na}^{+}$entering a neuron via a small but persistent sodium current may be effective in activating $\mathrm{I}_{\mathrm{KNa}}$, even in the absence of bulk internal $\mathrm{Na}^{+}$[10]. Furthermore, a recent study demonstrated that Slack is inhibited by divalent cations, most likely by an allosteric mode of action involving a His residue downstream S6 that is analogous to an inhibitory cation binding site in cyclic nucleotide gated channels [11]. We here demonstrate that a P2X3driven ion influx may both stimulate and inhibit Slack activity: (i) In HEK-Slack-P2X3 cells, the addition of the P2X3 agonist $\alpha, \beta$-meATP to the extracellular solution reduced $\mathrm{I}_{\mathrm{K}}$ in presence of $\mathrm{Ca}^{2+}$, whereas it increased $\mathrm{I}_{\mathrm{K}}$ under $\mathrm{Ca}^{2+}$-free conditions. (ii) In naive mice, paw injection of $\alpha, \beta$-meATP induced paw licking in a Slack-dependent manner that was blocked by pretreatment with the P2X3 antagonist AF353. The reduced paw licking of WT mice as compared to Slack ${ }^{-/-}$mice suggests that a P2X3-driven $\mathrm{Na}^{+}$influx activates Slack, which in turn limits the nocifensive behavior. (iii) After SNI, the paw licking evoked by $\alpha, \beta$-meATP was ameliorated in Slack ${ }^{-/-}$mice at late stages $(6-10 \mathrm{~min})$. The longer lasting paw licking in WT mice indicates that a P2X3-driven $\mathrm{Ca}^{2+}$ influx might inhibit Slack, thereby facilitating the nocifensive behavior. However, it should be taken into account that $\alpha, \beta$-meATP is an agonist not only at P2X3 but also at other P2X receptors $[42,43]$ and 
that AF353 also inhibits P2X2/3 heteromeric receptors [34]. Hence, P2X receptors different from P2X3 might theoretically contribute to the observed pain behavior after $\alpha, \beta$-meATP administration.

It is important to note that, in addition to ion influx, Slack activity may be modulated by protein kinase $\mathrm{A}[13,17], \mathrm{NAD}^{+}$[12], a $\mathrm{Na}^{+}$sensor in the RCK2 domain [44], and TMEM16C [14]. On the other hand, different firing modalities have been detected after incubation of trigeminal neurons with $\alpha, \beta$-meATP, suggesting that the co-expression of P2X3 with different interacting proteins might affect the firing responses [45]. In general, several factors have been identified that may interact with P2X receptors. In particular, $\mathrm{P} 2 \mathrm{X}$ receptors may physically interact with members of the Cys-loop receptor family such as nicotinic, $\mathrm{GABA}_{\mathrm{A} / \mathrm{C}}$, and $5-\mathrm{HT}_{3 \mathrm{~A}}$ receptors [46-50]. A recent study revealed that $\mathrm{P} 2 \mathrm{X} 3$ receptors in sensory neurons tightly associate with acid-sensing ion channels, thereby forming a protein complex that mediates unidirectional inhibition [51]. Furthermore, protein modifications such as glycosylation can affect the function of ion channels at the level of subunit assembly, protein trafficking, ligand binding, and channel opening. It has been shown that glycosylation also affects proper folding, oligomeric association, and compartmentalization of P2X3 receptors in neuronal cells [52,53]. Hence, the P2X3-Slack interaction we report here further contributes to the complexity of pain processing.

In conclusion, our study suggests that Slack controls the excitability of IB4-positive sensory neurons under neuropathic pain conditions and that their activity is regulated by P2X3 receptors. Thus, targeting these channels might prove to be a new direction for the treatment of neuropathic pain.

\section{Materials and Methods}

\subsection{Animals}

Generation of global Slack mutants (Slack ${ }^{-/-}$) by a targeted ablation of Slack gene Kcnt1 in murine embryonic stem cells in combination with a common Cre/loxP system has been described previously [15]. Experiments were performed in mice of either sex backcrossed onto a C57BL/6N background. Littermate mice were used in all behavioral and patch-clamp studies, and were investigated by an observer blinded for the genotype and treatment of the animals. In addition, C57BL/6N mice from Charles River laboratories (Sulzfeld, Germany) were used for qRT-PCR and immunoblotting analyses. Animals were housed on a 12/12 light/dark cycle with access to food and water ad libitum. All experiments adhered to the International Association for the Study of Pain (IASP) and the Animal Research: Reporting of In Vivo Experiments (ARRIVE) guidelines, the 3Rs principles, and were approved by our local Ethics Committees for Animal Research (Regierungspräsidium Darmstadt, Germany (protocol V54-19c20/15-F95/45 with approval date 3 May 2012 and protocol V54-19c20/15-FR/1013 with approval date 17 May 2018) and Landesamt für Natur, Umwelt und Verbraucherschutz NRW, Recklinghausen, Germany (protocol 84-02.04.2015.A119 with approval date 1 October 2015)).

\subsection{Behavioral Testing}

\subsubsection{Spared Nerve Injury Model of Neuropathic Pain}

The SNI model of neuropathic pain was performed as described previously [54,55]. Under isoflurane anesthesia and carprofen analgesia, the common peroneal and tibial nerve branches of the sciatic nerve were ligated with a 6-0 silk suture and approximately $1 \mathrm{~mm}$ of the two nerve branches was removed distally, whereas the sural nerve was left intact.

For testing mechanical sensitivity, mice were placed in boxes on an elevated metal mesh floor and habituated for at least $30 \mathrm{~min}$ before behavioral testing began. Calibrated von Frey filaments ranging from 0.40 to $39.2 \mathrm{mN}$ (0.02 to $4.0 \mathrm{~g}$; Ugo Basile, Gemonio, Italy) were applied to the lateral part of the hind paw (sural nerve area) until they bowed for 5 s. Only obvious withdrawal responses to the applied stimulus were recorded. The 50\% withdrawal thresholds were assessed using the up-down method [56,57] and calculated using an online algorithm (https: / /bioapps.shinyapps.io/von_frey_app / [58]). 
An automated dynamic weight-bearing (DWB) device (Bioseb, Vitrolles, France) was used to evaluate the dynamic weight distribution in mice after SNI. The system automatically records the average weight (in grams) that each limb exerts on a floor equipped with pressure transducers. A zone was considered valid when the following parameters were detected: $\geq 0.8 \mathrm{~g}$ on 1 captor with a minimum of 2 adjacent captors recording $\geq 1.0 \mathrm{~g}$. For testing, the mouse was placed in the chamber and allowed to move freely within the apparatus for $10 \mathrm{~min}$ and videotaped. After $5 \mathrm{~min}$ of acclimatization, the dynamic weight distribution was recorded for $5 \mathrm{~min}$. In all video sequences, the positions of the paws were manually validated by the observer $[59,60]$. The results were expressed as percent weight borne by the ipsilateral hind paw of total weight borne by both hind paws [61].

\subsection{2. $\alpha, \beta$-meATP-Induced Paw Licking}

The animals were placed into a plexiglass cylinder (diameter $30 \mathrm{~cm}$ ) and habituated for at least $30 \mathrm{~min}$. $\alpha, \beta$-Methylene adenosine $5^{\prime}$-triphosphate $(\alpha, \beta$-meATP; $12 \mathrm{nmol}$ in $12 \mu \mathrm{L} 0.9 \%$ saline [26]; Sigma-Aldrich, Darmstadt, Germany), AF353 (70 nmol in $12 \mu \mathrm{L} 0.9 \%$ saline [33]; Sigma-Aldrich), or 0.9\% saline (B. Braun, Melsungen, Germany) was injected into the dorsolateral hind paw and the time spent licking the injected paw was scored for $10 \mathrm{~min}$. In experiments with two compounds, AF353 was injected $10 \mathrm{~min}$ prior to $\alpha, \beta$-meATP.

\subsection{Quantitative Real-Time Reverse Transcription PCR}

Mice were killed by $\mathrm{CO}_{2}$ inhalation and their lumbar (L4-L5) DRGs were rapidly dissected, snap frozen in liquid nitrogen, and stored at $-80^{\circ} \mathrm{C}$. Total RNA was extracted under RNase-free conditions using an RNA isolation Kit (RNAqueous Micro Kit; Ambion/Life Technologies, Carlsbad, USA) according to the manufacturer's instructions, and DNase treated for 15 min to minimize genomic DNA contamination and quantified with a NanoDrop ND-1000 spectrophotometer (NanoDrop Technologies, Wilmington, USA). cDNA was synthesized from $200 \mathrm{ng}$ RNA, random hexamer primers, RT-Enhancer, and the Verso enzyme of the Verso Kit (Thermo Fisher Scientific, Frankfurt, Germany). Quantitative real-time reverse transcription PCR (qRT-PCR) was performed on a 7500 Fast Real-Time PCR System (Applied Biosystems/Life Technologies) using Taqman gene expression assays for Kcnt1 (catalog no. Mm01330653_m1), Kcnma1 (catalog no. Mm01119505_m1), Kcnt2 (catalog no. Mm01284549_m1), and GAPDH (catalog no. Mm99999915_g1), all purchased from Applied Biosystems. Reactions (total volume $10 \mu \mathrm{l}$ ) were performed in duplicate or triplicate by incubating at $95^{\circ} \mathrm{C}$ for $10 \mathrm{~min}$, followed by 40 cycles of $15 \mathrm{~s}$ at $95^{\circ} \mathrm{C}$ and $1 \mathrm{~min}$ at $60^{\circ} \mathrm{C}$. Water controls were included to ensure specificity. Relative expression of target gene levels was determined using the comparative $2^{-\Delta \Delta C t}$ method, with $\mathrm{Ct}$ indicating the cycle number at which the signal of the PCR product crossed an arbitrary threshold set within the exponential phase of the PCR. The amount of sample RNA was normalized to GAPDH.

\subsection{Immunostaining}

Mice were killed by $\mathrm{CO}_{2}$ and immediately perfused intracardially with $0.9 \%$ saline, followed by $1 \%$ paraformaldehyde in phosphate-buffered saline (PBS), pH 7.4. The lumbar (L4-L5) DRGs and spinal cord were dissected and cryoprotected in $20 \%$ sucrose overnight. Tissues were frozen in tissue-freezing medium (Leica, Nussloch, Germany) on dry ice, cryostat sectioned at a thickness of $14 \mu \mathrm{m}$, and stored at $-80^{\circ} \mathrm{C}$. For immunostaining, sections were permeabilized for $5 \mathrm{~min}$ in $0.1 \%$ Triton X-100 in PBS, blocked for $1 \mathrm{~h}$ using $10 \%$ normal goat serum and 3\% bovine serum albumin (BSA) in PBS, and incubated with primary antibodies diluted in $3 \%$ BSA in PBS overnight at $4{ }^{\circ} \mathrm{C}$ or for $2 \mathrm{~h}$ at room temperature. The following antibodies were used: mouse anti-slo2.2 (1:400, 75-051, NeuroMab; Davis, USA) [15], rabbit anti-P2X3 (1:800, AB5895, Sigma-Aldrich, Darmstadt, Germany) [18,62], rabbit anti-CGRP (1:800, PC205L, Calbiochem/Sigma-Aldrich) [15,63], 
mouse anti-NF200 (1:2000, N0142, Sigma-Aldrich) [64,65] and rabbit anti-tyrosin hydroxylase (1:400, AB152, Millipore/Sigma-Aldrich). Sections were then washed in PBS and stained with secondary antibodies conjugated with Alexa Fluor 488 (AF488) or Alexa Fluor 555 (1:1200, Thermo Fisher Scientific). For staining with tubulin $\beta 3$ (TUBB3), sections were incubated with AF488-conjuagted TUBB3 (1:1000, 801203, Biolegend, San Diego, USA) in PBS. For IB4 binding, sections were incubated with AF488-conjuagated IB4 (1:400, 121411, Invitrogen/Thermo Fisher Scientific) in PBS containing $1 \mathrm{mM} \mathrm{CaCl} 2 \cdot 2 \mathrm{H}_{2} \mathrm{O}, 1 \mathrm{mM} \mathrm{MgCl}$, $1 \mathrm{mM} \mathrm{MnCl}_{2}$, and $0.2 \%$ Triton X-100, pH 7.4). After immunostaining, slides were immersed for $5 \mathrm{~min}$ in $0.06 \%$ Sudan black B (in 70\% ethanol) to reduce lipofuscin-like autofluorescence [66], washed in PBS, and coverslipped. In double-labeling experiments, primary antibodies were consecutively incubated. Images were taken using an Eclipse Ni-U (Nikon, Düsseldorf, Germany) microscope equipped with a monochrome CCD camera, and were pseudocolored and superimposed. Adjustment of brightness and contrast was done using Adobe Photoshop 2020 software (Adobe Systems). Controls were performed by omitting the first or the second antibodies, or both, and by incubating tissues of Slack ${ }^{-/-}$mice.

For cell counting, serial DRG sections from 3 mice per genotype were processed and at least 3 sections per DRG per animal were counted. Only cells showing staining clearly above the background were included. Specificity of Slack immunoreactivity was confirmed by simultaneous staining of co-embedded tissues of WT and Slack ${ }^{-/-}$mice. The percentage of Slack-positive or P2X3-positive cells was calculated as a proportion of positive cells per total number of DRG neurons.

\subsection{Western Blot}

The lumbar (L4-L5) DRGs and spinal cord were rapidly dissected, frozen in liquid nitrogen, and stored at $-80{ }^{\circ} \mathrm{C}$ until use. For Slack detection, samples were homogenized in buffer containing $100 \mathrm{mM}$ Tris- $\mathrm{HCl}$ and $1 \mathrm{mM} \mathrm{MgCl}_{2}, \mathrm{pH} 8.0$, combined with a protease inhibitor mixture (Pierce Protease Inhibitor Mini Tablets; Thermo Scientific). After freezing for $30 \mathrm{~min}$ at $-80{ }^{\circ} \mathrm{C}$, samples were homogenized again. Then a sixfold volume of sucrose buffer ( $250 \mathrm{mM}$ sucrose, $10 \mathrm{mM}$ Tris- $\mathrm{HCl}$, pH 7.4, combined with protease inhibitor mixture) was added followed by centrifugation at $1000 \times g$ for $20 \mathrm{~min}$. The supernatant was collected and centrifuged at 20,000 x $\mathrm{g}$ for $20 \mathrm{~min}$, and the resulting pellets were resuspended in sucrose buffer [15]. For $\mathrm{P}_{2} \mathrm{X}_{3}$ detection, samples were homogenized in radioimmunoprecipitation assay (RIPA) buffer containing $150 \mathrm{mM} \mathrm{NaCl}, 50 \mathrm{mM}$ Tris, 0.5\% sodium deoxycholate, $0.1 \%$ SDS, and $1 \%$ Triton $\mathrm{X}-100, \mathrm{pH} 8.0$, combined with protease inhibitor mixture, and centrifuged at $12,000 \times g$ for $30 \mathrm{~min}$. Extracted proteins (30 $\mathrm{mg} / \mathrm{lane})$ were separated by SDS-PAGE and blotted onto a nitrocellulose membrane. After blocking nonspecific binding sites with blocking buffer (PBS with 3\% low-fat milk) for $1 \mathrm{~h}$, membranes were incubated with mouse anti-slo2.2 (1:500), rabbit anti-P2X $\mathrm{X}_{3}(1: 500)$, mouse anti- $\alpha$-tubulin (1:800, Millipore/Sigma-Aldrich), or mouse anti-GAPDH (1:2000; Thermo Fisher Scientific) dissolved in blocking buffer containing $0.1 \%$ Tween 20 overnight at $4{ }^{\circ} \mathrm{C}$. After incubation with secondary antibodies (IRDye ${ }^{\circledR} 680 \mathrm{LT}$ goat anti-mouse IgG , IRDye $^{\circledR}$ 680RD goat anti-rabbit IgG, IRDye ${ }^{\circledR}$ 800RD goat anti-rabbit IgG, or IRDye ${ }^{\circledR} 800$ RD goat anti-mouse IgG from LI-COR Bioscience, Bad Homburg, Germany) for $1 \mathrm{~h}$ at room temperature, proteins were detected using an Odyssey Infrared Imaging System or a C-DiGit blot scanner (LI-COR Bioscience).

\subsection{Patch Clamp Recordings}

A DRG neuron primary cell culture was prepared as described before [15]. Briefly, mice were killed by $\mathrm{CO}_{2}$ inhalation, and lumbar (L4-L5) DRGs were transferred to dulbecco's modified eagle's medium containing $50 \mu \mathrm{g} / \mathrm{mL}$ gentamicin (Sigma Aldrich). Following treatment with $500 \mathrm{U} / \mathrm{mL}$ collagenase IV and $2.5 \mathrm{U} / \mathrm{mL}$ dispase II for $30 \mathrm{~min}$ (both from Sigma Aldrich) and 0.05\% Trypsin/ethylenediaminetetraacetic acid (Gibco/Thermo Fisher Scientific) for $10 \mathrm{~min}$, cells were mechanically dissociated using a pipette. Isolated cells were transferred onto poly-D-lysine-coated (200 $\mu \mathrm{g} / \mathrm{mL}$, Sigma Aldrich) coverslips and cultured 
in TNB 100 medium supplemented with TNB 100 lipid protein complex, $100 \mu \mathrm{g} / \mathrm{mL}$ streptomycin, and penicillin (all from Biochrom, Berlin, Germany) at $37^{\circ} \mathrm{C}$ and $5 \% \mathrm{CO}_{2}$. To avoid neurite outgrowth, which could cause variations in expressed types and amounts of current, and to circumvent space clamp problems, the DRG neurons were studied within $24 \mathrm{~h}$ after plating $[15,67]$.

HEK293 cells stably transfected with human Kcnt1 (referred to as HEK-Slack cells; SB-HEK-KCa4.1; SB Drug Discovery, Lanarkshire, UK) were cultured in minimum essential medium with $10 \%$ fetal calf serum, supplemented with $2 \mathrm{mM} \mathrm{L}$-glutamine and $0.6 \mathrm{mg} / \mathrm{mL}$ G-418 (all from Gibco/Thermo Fisher Scientific) at $37^{\circ} \mathrm{C}$ and $5 \% \mathrm{CO}_{2}$. To obtain HEKSlack cells that additionally express P2X3 (referred to as HEK-Slack-P2X3 cells), transient transfections of human P2X3 (NM_002559) were done with a pIRES2-EGFP vector plasmid (kindly provided by Prof. Dr. Peter Illes, University of Leipzig, Germany) and Roti-Fect transfection reagent (Carl Roth, Karlsruhe, Germany) according to the manufacturer's instructions. Cells were split every 3 to 4 days and seeded 2 days before experiments.

Whole-cell voltage clamp recordings were conducted with an EPC 9 amplifier combined with Patchmaster software (HEKA Electronics, Lambrecht/Pfalz, Germany). Currents were filtered at $5 \mathrm{kHz}$ and sampled at $20 \mathrm{kHz}$. Offline analyses were performed using the Fitmaster software (HEKA Electronics). $\mathrm{I}_{\mathrm{K}}$ were elicited by protocols consisting of $500 \mathrm{~ms}$-long test pulses ranging from -120 to $+120 \mathrm{mV}$ in steps of $20 \mathrm{mV}$. The holding potential was $-70 \mathrm{mV}$. The pipette solution contained $140 \mathrm{mM} \mathrm{KCl}, 2 \mathrm{mM} \mathrm{MgCl} 2,5 \mathrm{mM}$ EGTA, and $10 \mathrm{mM}$ HEPES and was adjusted to $\mathrm{pH} 7.4$ with $\mathrm{KOH}$. The physiological external solution contained $140 \mathrm{mM} \mathrm{NaCl}, 5 \mathrm{mM} \mathrm{KCl}, 2 \mathrm{mM} \mathrm{CaCl}_{2}, 2 \mathrm{mM} \mathrm{MgCl}_{2}$, and $10 \mathrm{mM}$ HEPES and was adjusted to $\mathrm{pH} 7.4$ with $\mathrm{NaOH}$. In a $\mathrm{Na}^{+}$-free external solution, $\mathrm{NaCl}$ was replaced with $140 \mathrm{mM}$ choline chloride. In a $\mathrm{Ca}^{2+}$-free external solution, $\mathrm{CaCl}_{2}$ was replaced with $2 \mathrm{mM} \mathrm{MgCl}_{2}$ to obtain a final concentration of $4 \mathrm{mM} \mathrm{MgCl}_{2}$. Patch pipettes were fabricated with borosilicate glass (Science Products, Hofheim am Taunus, Germany) using a conventional puller (Flaming/Brown Micropipette Puller, Sutter Instruments, Novato, USA) and heat-polished to give a pipette resistance of 3-5 M . Shortly before a coverslip was mounted for recordings, it was dipped in extracellular solution containing $10 \mu \mathrm{g} / \mathrm{mL}$ fluorescein isothiocyanateconjugated IB4 (Sigma-Aldrich) for 5-10 min, and only IB4-binding DRG neurons were analyzed. All recordings were made at $37^{\circ} \mathrm{C} . \alpha, \beta$-meATP (Sigma-Aldrich) was added with a pipette to the bath chamber to reach a final concentration of $30 \mu \mathrm{M}$ [29], and $\mathrm{I}_{\mathrm{K}}$ was recorded $5 \mathrm{~min}$ after $\alpha, \beta$-meATP administration.

\subsection{Calcium Imaging}

Calcium imaging experiments were performed $24 \mathrm{~h}$ after DRG preparation [63]. Neurons were loaded with $5 \mu \mathrm{M}$ Fura-2-AM-ester (Biotium, Fremont, USA) in supplemented Neurobasal Medium for $45 \mathrm{~min}$ at $37^{\circ} \mathrm{C}$, transferred to the perfusion chamber, and continuously superfused with a physiological Ringer solution $\left(145 \mathrm{mM} \mathrm{NaCl}, 1.25 \mathrm{mM} \mathrm{CaCl}_{2}\right.$, $1 \mathrm{mM} \mathrm{MgCl} 2,5 \mathrm{mM} \mathrm{KCl}, 10 \mathrm{mM}$ Glucose, and $10 \mathrm{mM}$ HEPES, pH 7.4, adjusted with $\mathrm{NaOH}$ ). For calcium imaging, a Nikon Eclipse Ts2R inverse microscope equipped with a complete illumination system (DG4, Sutter Instruments), a Hamamatsu digital camera (ORCA-05G), Fura-2 filters, and a motorized microscope stage (Märzhäuser Wetzlar, Wetzlar, Germany) was used. Images were taken every $2 \mathrm{~s}$ at two wavelengths ( 340 and $380 \mathrm{~nm}$ ) and were processed using the NIS-Elements software (Nikon). Baseline measurements were performed in Ringer solution at a flow rate of $1-2 \mathrm{~mL} / \mathrm{min}$. For stimulation, $30 \mu \mathrm{M}$ $\alpha, \beta$-meATP dissolved in Ringer solution was applied by bath perfusion for $30 \mathrm{~s}$ at room temperature. At the end of each measurement, cells were stimulated for $20 \mathrm{~s}$ with $75 \mathrm{mM}$ $\mathrm{KCl}$ to identify viable neurons for evaluation. A calcium response was defined as a simultaneous increase at $340 \mathrm{~nm}$ and a decrease at $380 \mathrm{~nm}$, when the $340 / 380 \mathrm{~nm}$ ratio normalized to baseline exceeded $20 \%$ of the baseline level. Acquired images were displayed as the $340 / 380 \mathrm{~nm}$ ratio. 


\subsection{Experimental Design and Statistical Analyses}

Data are expressed as mean \pm SEM. All statistical analysis was performed with GraphPad Prism version 8 for windows. $p$ values $<0.05$ were considered statistically significant. Single comparisons were performed using Student's t-test. For behavioral experiments, two-way ANOVA (time x genotype) was used to measure effects across time between groups. Multiple comparisons between groups were performed using Sidak's correction. Numbers of experiments (cells or mice) and statistical results are provided in the results section and the figure legends.

Supplementary Materials: The following are available online at https:/ /www.mdpi.com/1422-006 7/22/1/405/s1.

Author Contributions: Conceptualization, R.L. (Ruirui Lu), P.R., R.L. (Robert Lukowski), and A.S.; Methodology, R.L. (Ruirui Lu), K.M., R.E. and A.B. (Anne Bausch); Investigation, R.L. (Ruirui Lu), K.M., F.Z., C.F., A.B. (Annika Balzulat), P.E. and J.P.; writing—original draft preparation, R.L. (Ruirui Lu) and K.M.; writing—review and editing, R.L. (Ruirui Lu) and A.S.; supervision, R.L. (Ruirui Lu) and A.S.; project administration, R.L. (Ruirui Lu); funding acquisition, R.L. (Ruirui Lu) and A.S. All authors have read and agreed to the published version of the manuscript.

Funding: This research was funded by the Else Kröner-Fresenius-Stiftung (2018_A95 to A.S.) and the Deutsche Forschungsgemeinschaft (LU 2514/1-1 to R.L. (Ruirui Lu)).

Institutional Review Board Statement: All animal experiments in this study were approved by our local Ethics Committees for Animal Research (Regierungspräsidium Darmstadt, Germany [protocol V54-19c20/15-F95/45 with approval date 3 May 2012 and protocol V54-19c20/15-FR/1013 with approval date 17 May 2018] and Landesamt für Natur, Umwelt und Verbraucherschutz NRW, Recklinghausen, Germany [protocol 84-02.04.2015.A119 with approval date 1 October 2015]).

Informed Consent Statement: Not applicable.

Data Availability Statement: Data is contained within the article or supplementary material.

Acknowledgments: We thank Sylvia Oßwald, Cyntia Schäfer, Uli Hermanni, and Clement KabagemaBilan for excellent technical assistance and Peter Illes, Leipzig University, Germany, for providing the P2X3 vector plasmid.

Conflicts of Interest: The authors declare no conflict of interest.

\section{Abbreviations}

$\begin{array}{ll}\alpha, \beta \text {-meATP } & \alpha, \beta \text {-Methylene adenosine } 5^{\prime} \text {-triphosphate } \\ \text { AF488 } & \text { Alexa Fluor 488 } \\ \text { CGRP } & \text { Calcitonin gene-related peptide } \\ \text { DRG } & \text { Dorsal root ganglion } \\ \text { GFP } & \text { Green fluorescent protein } \\ \text { IB4 } & \text { Griffonia simplicifolia isolectin B4 } \\ \text { I }_{K} & \mathrm{~K}^{+} \text {current } \\ \text { I }_{\text {KNa }} & \mathrm{Na}^{+} \text {-activated outward } \mathrm{K}^{+} \text {current } \\ \text { I-V } & \text { Current-Voltage } \\ \text { NF200 } & \text { Neurofilament } 200 \\ \text { PBS } & \text { Phosphate-buffered saline } \\ \text { qRT-PCR } & \text { Quantitative real-time reverse transcription PCR } \\ \text { RIPA } & \text { Radioimmunoprecipitation assay } \\ \text { Slack } & \text { Sequence like a Ca }{ }^{2+} \text {-activated } \mathrm{K}^{+} \text {channel } \\ \text { SNI } & \text { Spared nerve injury } \\ \text { TUBB3 } & \text { Tubulin } \beta 3 \\ \text { WT } & \text { Wild-type }\end{array}$




\section{References}

1. $\quad$ van Hecke, O.; Austin, S.K.; Khan, R.A.; Smith, B.H.; Torrance, N. Neuropathic pain in the general population: A systematic review of epidemiological studies. Pain 2014, 155, 654-662. [CrossRef] [PubMed]

2. Finnerup, N.B.; Attal, N.; Haroutounian, S.; McNicol, E.; Baron, R.; Dworkin, R.H.; Gilron, I.; Haanpää, M.; Hansson, P.; Jensen, T.S.; et al. Pharmacotherapy for neuropathic pain in adults: A systematic review and meta-analysis. Lancet Neurol. 2015, 14, 162-173. [CrossRef]

3. Tsantoulas, C.; Denk, F.; Signore, M.; Nassar, M.A.; Futai, K.; McMahon, S.B. Mice lacking Kcns1 in peripheral neurons show increased basal and neuropathic pain sensitivity. Pain 2018, 159, 1641-1651. [CrossRef] [PubMed]

4. Cohen, S.P.; Mao, J. Neuropathic pain: Mechanisms and their clinical implications. BMJ 2014, 348. [CrossRef]

5. Chen, L.; Mao, J. Update on neuropathic pain treatment: Ion channel blockers and gabapentinoids. Curr. Pain Headache Rep. 2013, 17. [CrossRef]

6. Waxman, S.G.; Zamponi, G.W. Regulating excitability of peripheral afferents: Emerging ion channel targets. Nat. Neurosci. 2014, 17, 153-163. [CrossRef]

7. Hite, R.K.; MacKinnon, R. Structural Titration of Slo2.2, a Na ${ }^{+}$-Dependent $\mathrm{K}^{+}$Channel. Cell 2017, 168, 390-399.e11. [CrossRef]

8. Bader, C.R.; Bernheim, L.; Bertrand, D. Sodium-activated potassium current in cultured avian neurones. Nature 1985, 317, 540-542. [CrossRef]

9. Yuan, A.; Santi, C.M.; Wei, A.; Wang, Z.W.; Pollak, K.; Nonet, M.; Kaczmarek, L.; Crowder, C.M.; Salkoff, L. The sodium-activated potassium channel is encoded by a member of the Slo gene family. Neuron 2003, 37, 765-773. [CrossRef]

10. Budelli, G.; Hage, T.A.; Wei, A.; Rojas, P.; Jong, Y.J.; O’Malley, K.; Salkoff, L. Na ${ }^{+}$-activated K ${ }^{+}$channels express a large delayed outward current in neurons during normal physiology. Nat. Neurosci. 2009, 12, 745-750. [CrossRef]

11. Budelli, G.; Sun, Q.; Ferreira, J.; Butler, A.; Santi, C.M.; Salkoff, L. SLO2 Channels Are Inhibited by All Divalent Cations That Activate SLO1 K+ Channels. J. Biol. Chem. 2016, 291, 7347-7356. [CrossRef] [PubMed]

12. Tamsett, T.J.; Picchione, K.E.; Bhattacharjee, A. NAD ${ }^{+}$activates $\mathrm{K}_{\mathrm{Na}}$ channels in dorsal root ganglion neurons. J. Neurosci. 2009, 29, 5127-5134. [CrossRef] [PubMed]

13. Nuwer, M.O.; Picchione, K.E.; Bhattacharjee, A. PKA-induced internalization of slack $\mathrm{K}_{\mathrm{Na}}$ channels produces dorsal root ganglion neuron hyperexcitability. J. Neurosci. 2010, 30, 14165-14172. [CrossRef] [PubMed]

14. Huang, F.; Wang, X.; Ostertag, E.M.; Nuwal, T.; Huang, B.; Jan, Y.N.; Basbaum, A.I.; Jan, L.Y. TMEM16C facilitates Na ${ }^{+}$-activated $\mathrm{K}^{+}$currents in rat sensory neurons and regulates pain processing. Nat. Neurosci. 2013, 16, 1284-1290. [CrossRef]

15. Lu, R.; Bausch, A.E.; Kallenborn-Gerhardt, W.; Stoetzer, C.; Debruin, N.; Ruth, P.; Geisslinger, G.; Leffler, A.; Lukowski, R.; Schmidtko, A. Slack channels expressed in sensory neurons control neuropathic pain in mice. J. Neurosci. 2015, 35, 1125-1135. [CrossRef]

16. Evely, K.M.; Pryce, K.D.; Bausch, A.E.; Lukowski, R.; Ruth, P.; Haj-Dahmane, S.; Bhattacharjee, A. Slack K ${ }_{\text {Na }}$ Channels Influence Dorsal Horn Synapses and Nociceptive Behavior. Mol. Pain 2017, 13. [CrossRef]

17. Gururaj, S.; Evely, K.M.; Pryce, K.D.; Li, J.; Qu, J.; Bhattacharjee, A. Protein kinase A-induced internalization of Slack channels from the neuronal membrane occurs by adaptor protein-2/clathrin-mediated endocytosis. J. Biol. Chem. 2017, 292, 19304-19314. [CrossRef]

18. Martinez-Espinosa, P.L.; Wu, J.; Yang, C.; Gonzalez-Perez, V.; Zhou, H.; Liang, H.; Xia, X.M.; Lingle, C.J. Knockout of Slo2.2 enhances itch, abolishes $\mathrm{K}_{\mathrm{Na}}$ current, and increases action potential firing frequency in DRG neurons. eLife 2015, 4. [CrossRef]

19. Schmiedl, S.; Peters, D.; Schmalz, O.; Mielke, A.; Rossmanith, T.; Diop, S.; Piefke, M.; Thurmann, P.; Schmidtko, A. Loxapine for Treatment of Patients With Refractory, Chemotherapy-Induced Neuropathic Pain: A Prematurely Terminated Pilot Study Showing Efficacy But Limited Tolerability. Front. Pharmacol. 2019, 10, 838. [CrossRef]

20. Burnstock, G. Purinergic Mechanisms and Pain. Adv. Pharmacol. 2016, 75, 91-137.

21. Krajewski, J.L. P2X $\mathrm{X}_{3}$-Containing Receptors as Targets for the Treatment of Chronic Pain. Neurotherapeutics 2020, 17, 826-838. [CrossRef] [PubMed]

22. Pryce, K.D.; Powell, R.; Agwa, D.; Evely, K.M.; Sheehan, G.D.; Nip, A.; Tomasello, D.L.; Gururaj, S.; Bhattacharjee, A. Magi-1 scaffolds $\mathrm{Na}_{\mathrm{V}} 1.8$ and Slack $\mathrm{K}_{\mathrm{Na}}$ channels in dorsal root ganglion neurons regulating excitability and pain. FASEB J. 2019, 33, 7315-7330. [CrossRef] [PubMed]

23. Usoskin, D.; Furlan, A.; Islam, S.; Abdo, H.; Lonnerberg, P.; Lou, D.; Hjerling-Leffler, J.; Haeggstrom, J.; Kharchenko, O.; Kharchenko, P.V.; et al. Unbiased classification of sensory neuron types by large-scale single-cell RNA sequencing. Nat. Neurosci. 2015, 18, 145-153. [CrossRef] [PubMed]

24. Vulchanova, L.; Riedl, M.S.; Shuster, S.J.; Stone, L.S.; Hargreaves, K.M.; Buell, G.; Surprenant, A.; North, R.A.; Elde, R. P2X 3 is expressed by DRG neurons that terminate in inner lamina II. Eur. J. Neurosci. 1998, 10, 3470-3478. [CrossRef] [PubMed]

25. Fabbretti, E. ATP $\mathrm{P}_{2} \mathrm{X}_{3}$ receptors and neuronal sensitization. Front. Cell Neurosci. 2013, 7, 236. [CrossRef] [PubMed]

26. Chen, Y.; Li, G.W.; Wang, C.; Gu, Y.; Huang, L.Y. Mechanisms underlying enhanced P2X receptor-mediated responses in the neuropathic pain state. Pain 2005, 119, 38-48. [CrossRef] [PubMed]

27. Xiang, Z.; Xiong, Y.; Yan, N.; Li, X.; Mao, Y.; Ni, X.; He, C.; LaMotte, R.H.; Burnstock, G.; Sun, J. Functional up-regulation of P2X 3 receptors in the chronically compressed dorsal root ganglion. Pain 2008, 140, 23-34. [CrossRef]

28. Richards, D.; Gever, J.R.; Ford, A.P.; Fountain, S.J. Action of MK-7264 (gefapixant) at human P2X $\mathrm{X}_{3}$ and $\mathrm{P} 2 \mathrm{X}_{2 / 3}$ receptors and in vivo efficacy in models of sensitisation. Br. J. Pharmacol. 2019, 176, 2279-2291. [CrossRef] 
29. Hausmann, R.; Bodnar, M.; Woltersdorf, R.; Wang, H.; Fuchs, M.; Messemer, N.; Qin, Y.; Gunther, J.; Riedel, T.; Grohmann, M.; et al. ATP binding site mutagenesis reveals different subunit stoichiometry of functional $\mathrm{P}_{2} \mathrm{X}_{2 / 3}$ and $\mathrm{P} 2 \mathrm{X}_{2 / 6}$ receptors. J. Biol. Chem. 2012, 287, 13930-13943. [CrossRef]

30. Virginio, C.; North, R.A.; Surprenant, A. Calcium permeability and block at homomeric and heteromeric $\mathrm{P} 2 \mathrm{X}_{2}$ and $\mathrm{P} 2 \mathrm{X}_{3}$ receptors, and P2X receptors in rat nodose neurones. J. Physiol. 1998, 510, 27-35. [CrossRef]

31. Simonetti, M.; Fabbro, A.; D'Arco, M.; Zweyer, M.; Nistri, A.; Giniatullin, R.; Fabbretti, E. Comparison of P2X and TRPV1 receptors in ganglia or primary culture of trigeminal neurons and their modulation by NGF or serotonin. Mol. Pain 2006, 2. [CrossRef] [PubMed]

32. Grundy, L.; Daly, D.M.; Chapple, C.; Grundy, D.; Chess-Williams, R. TRPV1 enhances the afferent response to P2X receptor activation in the mouse urinary bladder. Sci. Rep. 2018, 8. [CrossRef] [PubMed]

33. Kaan, T.K.; Yip, P.K.; Patel, S.; Davies, M.; Marchand, F.; Cockayne, D.A.; Nunn, P.A.; Dickenson, A.H.; Ford, A.P.; Zhong, Y.; et al. Systemic blockade of $\mathrm{P} 2 \mathrm{X}_{3}$ and $\mathrm{P} 2 \mathrm{X}_{2 / 3}$ receptors attenuates bone cancer pain behaviour in rats. Brain 2010, 133, 2549-2564. [CrossRef] [PubMed]

34. Gever, J.R.; Soto, R.; Henningsen, R.A.; Martin, R.S.; Hackos, D.H.; Panicker, S.; Rubas, W.; Oglesby, I.B.; Dillon, M.P.; Milla, M.E.; et al. AF-353, a novel, potent and orally bioavailable P2X3/P2X2/3 receptor antagonist. Br. J. Pharmacol. 2010, 160, 1387-1398. [CrossRef] [PubMed]

35. Fabbretti, E. P2X3 receptors are transducers of sensory signals. Brain Res. Bull. 2019, 151, 119-124. [CrossRef] [PubMed]

36. Zeisel, A.; Hochgerner, H.; Lonnerberg, P.; Johnsson, A.; Memic, F.; van der Zwan, J.; Haring, M.; Braun, E.; Borm, L.E.; La Manno, G.; et al. Molecular Architecture of the Mouse Nervous System. Cell 2018, 174, 999-1014.e22. [CrossRef] [PubMed]

37. Tsantoulas, C.; McMahon, S.B. Opening paths to novel analgesics: The role of potassium channels in chronic pain. Trends Neurosci. 2014, 37, 146-158. [CrossRef]

38. Tsantoulas, C.; Zhu, L.; Shaifta, Y.; Grist, J.; Ward, J.P.; Raouf, R.; Michael, G.J.; McMahon, S.B. Sensory neuron downregulation of the Kv9.1 potassium channel subunit mediates neuropathic pain following nerve injury. J. Neurosci. 2012, 32, 17502-17513. [CrossRef]

39. Liang, L.; Gu, X.; Zhao, J.Y.; Wu, S.; Miao, X.; Xiao, J.; Mo, K.; Zhang, J.; Lutz, B.M.; Bekker, A.; et al. G9a participates in nerve injury-induced Kcna2 downregulation in primary sensory neurons. Sci. Rep. 2016, 6. [CrossRef]

40. Calvo, M.; Richards, N.; Schmid, A.B.; Barroso, A.; Zhu, L.; Ivulic, D.; Zhu, N.; Anwandter, P.; Bhat, M.A.; Court, F.A.; et al. Altered potassium channel distribution and composition in myelinated axons suppresses hyperexcitability following injury. eLife 2016, 5. [CrossRef]

41. Nanou, E.; Kyriakatos, A.; Bhattacharjee, A.; Kaczmarek, L.K.; Paratcha, G.; El Manira, A. Na ${ }^{+}$-mediated coupling between AMPA receptors and $\mathrm{K}_{\mathrm{Na}}$ channels shapes synaptic transmission. Proc. Natl. Acad. Sci. USA 2008, 105, 20941-20946. [CrossRef] [PubMed]

42. Wildman, S.S.; Brown, S.G.; Rahman, M.; Noel, C.A.; Churchill, L.; Burnstock, G.; Unwin, R.J.; King, B.F. Sensitization by extracellular $\mathrm{Ca}^{2+}$ of rat $\mathrm{P}_{2} \mathrm{X}_{5}$ receptor and its pharmacological properties compared with rat $\mathrm{P} 2 \mathrm{X}_{1}$. Mol. Pharmacol. 2002, 62, 957-966. [CrossRef] [PubMed]

43. Mo, G.; Bernier, L.P.; Zhao, Q.; Chabot-Dore, A.J.; Ase, A.R.; Logothetis, D.; Cao, C.Q.; Seguela, P. Subtype-specific regulation of $\mathrm{P}_{2} \mathrm{X}_{3}$ and $\mathrm{P} 2 \mathrm{X}_{2 / 3}$ receptors by phosphoinositides in peripheral nociceptors. Mol. Pain 2009, 5. [CrossRef] [PubMed]

44. Zhang, Z.; Rosenhouse-Dantsker, A.; Tang, Q.Y.; Noskov, S.; Logothetis, D.E. The RCK2 domain uses a coordination site present in Kir channels to confer sodium sensitivity to Slo2.2 channels. J. Neurosci. 2010, 30, 7554-7562. [CrossRef]

45. Hullugundi, S.K.; Ferrari, M.D.; van den Maagdenberg, A.M.; Nistri, A. The mechanism of functional up-regulation of P2X 3 receptors of trigeminal sensory neurons in a genetic mouse model of familial hemiplegic migraine type 1 (FHM-1). PLoS ONE 2013, 8, e60677. [CrossRef]

46. Khakh, B.S.; Zhou, X.; Sydes, J.; Galligan, J.J.; Lester, H.A. State-dependent cross-inhibition between transmitter-gated cation channels. Nature 2000, 406, 405-410. [CrossRef]

47. Barajas-Lopez, C.; Montano, L.M.; Espinosa-Luna, R. Inhibitory interactions between 5-HT 3 and P2X channels in submucosal neurons. Am. J. Physiol. Gastrointest. Liver Physiol. 2002, 283, G1238-G1248. [CrossRef]

48. Boue-Grabot, E.; Emerit, M.B.; Toulme, E.; Seguela, P.; Garret, M. Cross-talk and co-trafficking between rho1/GABA receptors and ATP-gated channels. J. Biol. Chem. 2004, 279, 6967-6975. [CrossRef]

49. Xia, R.; Mei, Z.Z.; Milligan, C.; Jiang, L.H. Inhibitory interaction between $\mathrm{P}_{2} \mathrm{X}_{4}$ and $\mathrm{GABA}_{\mathrm{C}} \rho 1$ receptors. Biochem. Biophys. Res. Commun. 2008, 375, 38-43. [CrossRef]

50. Khakh, B.S.; Fisher, J.A.; Nashmi, R.; Bowser, D.N.; Lester, H.A. An angstrom scale interaction between plasma membrane ATP-gated P2 $X_{2}$ and $\alpha_{4} \beta_{2}$ nicotinic channels measured with fluorescence resonance energy transfer and total internal reflection fluorescence microscopy. J. Neurosci. 2005, 25, 6911-6920. [CrossRef]

51. Stephan, G.; Huang, L.; Tang, Y.; Vilotti, S.; Fabbretti, E.; Yu, Y.; Norenberg, W.; Franke, H.; Goloncser, F.; Sperlagh, B.; et al. Author Correction: The ASIC3/P2X 3 cognate receptor is a pain-relevant and ligand-gated cationic channel. Nat. Commun. 2018, 9 , 3351. [CrossRef] [PubMed]

52. Vacca, F.; Amadio, S.; Sancesario, G.; Bernardi, G.; Volonte, C. P2X 3 receptor localizes into lipid rafts in neuronal cells. J. Neurosci. Res. 2004, 76, 653-661. [CrossRef] [PubMed] 
53. Vacca, F.; D'Ambrosi, N.; Nestola, V.; Amadio, S.; Giustizieri, M.; Cucchiaroni, M.L.; Tozzi, A.; Velluz, M.C.; Mercuri, N.B.; Volonte, C. N-Glycans mutations rule oligomeric assembly and functional expression of $\mathrm{P}_{2} \mathrm{X}_{3}$ receptor for extracellular ATP. Glycobiology 2011, 21, 634-643. [CrossRef] [PubMed]

54. Decosterd, I.; Woolf, C.J. Spared nerve injury: An animal model of persistent peripheral neuropathic pain. Pain 2000, 87, 149-158. [CrossRef]

55. Bourquin, A.F.; Suveges, M.; Pertin, M.; Gilliard, N.; Sardy, S.; Davison, A.C.; Spahn, D.R.; Decosterd, I. Assessment and analysis of mechanical allodynia-like behavior induced by spared nerve injury (SNI) in the mouse. Pain 2006, 122, 14.e1-14.e14. [CrossRef]

56. Chaplan, S.R.; Bach, F.W.; Pogrel, J.W.; Chung, J.M.; Yaksh, T.L. Quantitative assessment of tactile allodynia in the rat paw. J. Neurosci. Methods 1994, 53, 55-63. [CrossRef]

57. Dixon, W.J. Efficient analysis of experimental observations. Annu. Rev. Pharmacol. Toxicol. 1980, 20, 441-462. [CrossRef]

58. Christensen, S.L.; Hansen, R.B.; Storm, M.A.; Olesen, J.; Hansen, T.F.; Ossipov, M.; Izarzugaza, J.M.G.; Porreca, F.; Kristensen, D.M. Von Frey testing revisited: Provision of an online algorithm for improved accuracy of $50 \%$ thresholds. Eur. J. Pain. 2020, 24, 783-790. [CrossRef]

59. Pitzer, C.; Kuner, R.; Tappe-Theodor, A. EXPRESS: Voluntary and evoked behavioral correlates in neuropathic pain states under different housing conditions. Mol. Pain 2016, 12. [CrossRef]

60. Stark, A.; Schwenk, R.; Wack, G.; Zuchtriegel, G.; Hatemler, M.G.; Brautigam, J.; Schmidtko, A.; Reichel, C.A.; Bischoff, I.; Furst, R. Narciclasine exerts anti-inflammatory actions by blocking leukocyte-endothelial cell interactions and down-regulation of the endothelial TNF receptor 1. FASEB J. 2019, 33, 8771-8781. [CrossRef]

61. Majuta, L.A.; Longo, G.; Fealk, M.N.; McCaffrey, G.; Mantyh, P.W. Orthopedic surgery and bone fracture pain are both significantly attenuated by sustained blockade of nerve growth factor. Pain 2015, 156, 157-165. [CrossRef] [PubMed]

62. Han, L.; Ma, C.; Liu, Q.; Weng, H.J.; Cui, Y.; Tang, Z.; Kim, Y.; Nie, H.; Qu, L.; Patel, K.N.; et al. A subpopulation of nociceptors specifically linked to itch. Nat. Neurosci. 2013, 16, 174-182. [CrossRef] [PubMed]

63. Lu, R.; Lukowski, R.; Sausbier, M.; Zhang, D.D.; Sisignano, M.; Schuh, C.D.; Kuner, R.; Ruth, P.; Geisslinger, G.; Schmidtko, A. $\mathrm{BK}_{\mathrm{Ca}}$ channels expressed in sensory neurons modulate inflammatory pain in mice. Pain 2014, 155, 556-565. [CrossRef] [PubMed]

64. Petersen, J.; Mergia, E.; Kennel, L.; Drees, O.; Steubing, R.D.; Real, C.I.; Kallenborn-Gerhardt, W.; Lu, R.; Friebe, A.; Koesling, D.; et al. Distinct functions of soluble guanylyl cyclase isoforms NO-GC1 and NO-GC2 in inflammatory and neuropathic pain processing. Pain 2018, 160, 607-618. [CrossRef]

65. Kallenborn-Gerhardt, W.; Hohmann, S.W.; Syhr, K.M.; Schroder, K.; Sisignano, M.; Weigert, A.; Lorenz, J.E.; Lu, R.; Brune, B.; Brandes, R.P.; et al. Nox2-dependent signaling between macrophages and sensory neurons contributes to neuropathic pain hypersensitivity. Pain 2014, 155, 2161-2170. [CrossRef]

66. Schmidtko, A.; Gao, W.; Sausbier, M.; Rauhmeier, I.; Sausbier, U.; Niederberger, E.; Scholich, K.; Huber, A.; Neuhuber, W.; Allescher, H.D.; et al. Cysteine-rich protein 2, a novel downstream effector of cGMP/cGMP-dependent protein kinase I-mediated persistent inflammatory pain. J. Neurosci. 2008, 28, 1320-1330. [CrossRef]

67. Everill, B.; Kocsis, J.D. Nerve growth factor maintains potassium conductance after nerve injury in adult cutaneous afferent dorsal root ganglion neurons. Neuroscience 2000, 100, 417-422. [CrossRef] 